\title{
Study of the technical guidance application on the specific allocation fund (DAK) for road infrastructure (2017): Case study in the Public Works Office of West Sumatra
}

\author{
Tuti Kurniasih ${ }^{1}$, Bayu Martanto Adji ${ }^{1, *}$, and Taufika Ophiyandri ${ }^{1}$ \\ ${ }^{1}$ Department of Civil Engineering, Universitas Andalas, Padang, Indonesia
}

\begin{abstract}
The specific allocation fund (DAK) is one of the central government programs used to provide the road infrastructure in regions of Indonesia. DAK 2017 used the technical guidelines for the implementation of the specific allocation fund in the infrastructure sector. The technical guidelines are a very important guideline in the implementation of DAK since the guidelines are composed according to the aim of ensuring the implementation or management of DAK for road infrastructure in accordance with the provisions, which should be orderly in their implementation and on target. A number of problems have been identified during the implementation: for instance, a low absorption of funds due to delays in the procurement process as well as changes in the organisational structure of DAK. Therefore, this research aimed to fill in the gaps in the issues in order to solve the problems encountered in the implementation of DAK for road infrastructure. This research was focused on the implementation of DAK in Payakumbuh, Bukittinggi, and Solok City, which are known as centres of economic growth in West Sumatra. They also support Padang city, the capital of the West Sumatra province. The study was mainly centred on the application of the technical guidance and any problems encountered. It was a qualitative research study and it applied the triangulation method as the validated approach. The results show that both Payakumbuh and Solok City have fulfilled the ten indicators of DAK implementation, on the other hand, Bukittinggi city can only fulfil nine indicators. In relation to the indicators of the handling program's determination, the three other study sites did not apply what was instructed in the technical guideline in terms of conducting a survey to determine the road condition. In addition, these sites also did not send quarterly reports to the inspectors.
\end{abstract}

\section{Introduction}

A road is a land transportation network system that is structured and integrated. Based on 2014 's statistical data, provincial and district/ municipal roads constitute $90 \%$ of the road network in Indonesia. The percentage of provincial roads which are in a stable condition is

\footnotetext{
*Corresponding author: bayumartantoadji@ymail.com
} 
$68 \%$ of the total length of $46,164 \mathrm{~km}$, and district/ municipal roads make up $59 \%$ of the total length of $376,102 \mathrm{~km}$. The stability of the provincial/ district/ municipal roads is very important in relation to supporting national road infrastructures, namely as a liaison between the Central Activities Area (PKW) and Local Activity Centre (PKL), in addition to the National Centre of Activities (PKN) [1].

Balancing Funds are funds sourced from APBN revenue allocated to regions (autonomous) to fund regional needs in the context of implementing decentralization. The amount of the Balance Fund is set every year according to APBN. The specific allocation fund (DAK) is a fund sourced from APBN revenues allocated to a particular region, aiming to provide funding for particular needs in terms of both regional affairs and national priorities [2]. To ensure that the DAK is used properly and as it is legally responsible for the construction of road infrastructure, the Ministry of Public Works and Public Housing (PUPR) has issued technical guidelines for DAK to apply to infrastructure. For the implementation of 2017's road DAK, the PUPR Ministry issued a regulation from the Ministry of Public Works and Public Housing; No. 33/PRT/M/2016 on Technical Guidelines for the Implementation of Specific Allocation Funds for the Infrastructure Sector.

The implementation of DAK for roads in 2017 was not without any obstacles. The low budget absorption of DAK by the local government was an issue in its implementation, and this was caused by 1) a failure in relation to the procurement of jobs, 2) a delay in the absorption of funds due to late procurement processing, thus also affecting the reduction of the duration of work, and 3) changes in the organizational structure of the DAK managers. These are problems that are generally found in most DAK recipients in Indonesia, as this situation was also found in West Sumatra Province. The location of the research was in Payakumbuh, Bukittinggi, and Solok. These cities were selected because they were in demand have their roads infrastructure improved due to their main role in West Sumatra economically.

The main purpose of this research is to investigate how the implementation of road DAK was carried out in the cities of Payakumbuh, Bukittinggi, and Solok. The specific objectives of this research study are: 1) To find out whether DAK implementation for roads in the three cities in West Sumatera Province in 2017 was following the Regulation of the Ministry of Public Works and Public Housing No. 33/PRT/M/2016 on Technical Guidelines for the Implementation of Specific Allocation Funds for the Infrastructure Sector; 2) To reveal the obstacles faced in DAK implementation for roads in 2017; 3) To provide problem-solving recommendations.

\section{Methodology}

This research used the method of content analysis with a qualitative descriptive approach. The qualitative approach allowed the researchers to understand, in-depth, how the DAK implementation process was executed and revealed the problems encountered in the process.

This research used both primary data and secondary data. The primary data was collected through in-depth interviews with selected sources using the purposive sampling technique. The type of interview used in this study was a semi-trashed interview to reveal any problems thoroughly. This is as the interviewees can bluntly express his or her opinion and ideas [3]. The interviewees in this research study were 3 DAK recipients from the Public Works Department of the study sites and three inspectors from the Ministry of Public Works and People's Housing responsible for verifying and monitoring DAK for the roads. Before the in-depth interviews, questionnaires were developed based on the implementation of the DAK Technical Guidelines of 2017, and the interviews were conducted to find out whether the questionnaires could be responded to appropriately by the interviewees. The 
secondary data used were the DAK Technical data, DAK implementation data, DAK Emonitoring data and DAK road monitoring reports from 2017.

The method used was qualitative content analysis. The results of the content analysis were then verified by the triangulation technique by checking the data from the same source using different techniques [4]. The qualitative content analysis emphasizes textual research and symbols in particular contexts. This study aimed to map the content of the message to check the meaning, themes and patterns that are not visible (latent content) in certain text messages and that are not used to calculate the data in the content of the message content in a statistical manner [5].

The secondary data analysis was conducted before the researcher did the field research. The analysis was performed to determine the components and indicators of DAK implementation for the roads in 2017. The determination of the components and indicators was based on the regulation from the Ministry of Public Works and Public Housing No. 33/PRT/M/2016 on the Technical Guidelines for the Implementation of Specific Allocation Funds for the Infrastructure Sector [6]. The components and indicators are permanently fixed because they are based on standard rules. After determining the components and indicators, the researcher improved the instrument design of the interview. The research methodology used in this study has been illustrated in the Fig. 1 flow diagram below.

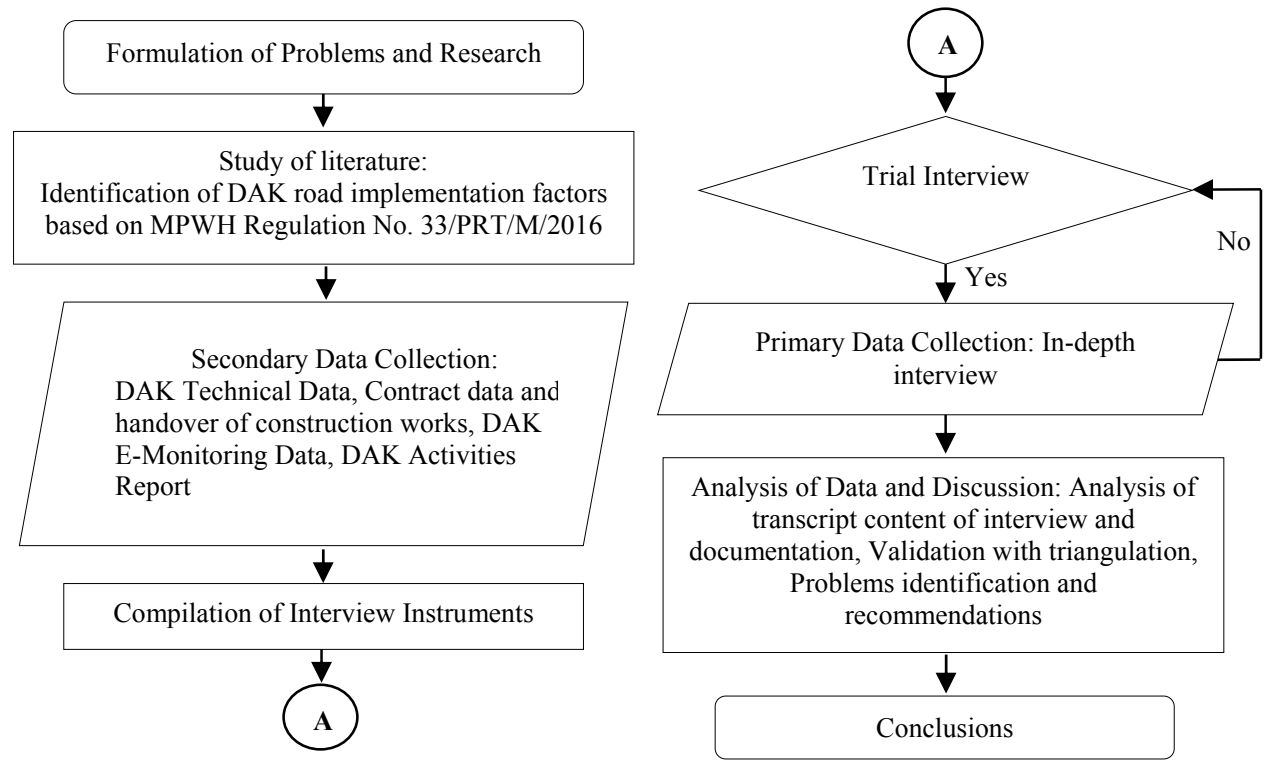

Fig. 1. Flowchart of the research.

The content analysis technique is an analysis that relies on codes found in the data recording text from an interview. Content analysis in this study began with the coding of the interview transcripts that had already been done in advance. The codes were categories developed in line with the purpose of the study. Furthermore, the codes became tools that helped to classify the data systematically. The flow of qualitative content analysis was adapted from Miles and Hubberman, as shown in Fig. 2 [7].

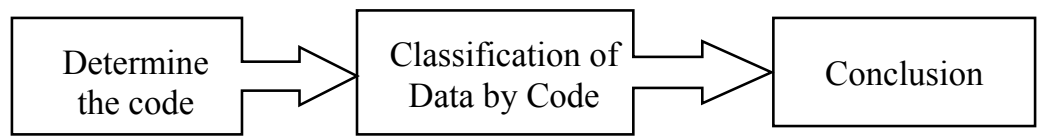

Fig. 2. Content analysis process [7]. 
After being concluded, the data was compiled in the form of a checklist of the implemented activities instructed in DAK. Afterward, the validity of the data was tested using the triangulation technique by comparing the three results of the data processing which was subsequently summarised. The triangulation technique process has been illustrated in Fig. 3. Some of the problems of DAK also appeared in the coding results. Hence, the recommendations to solve the problems has been shown in Fig. 4.

Fig. 3. Triangulation technique.
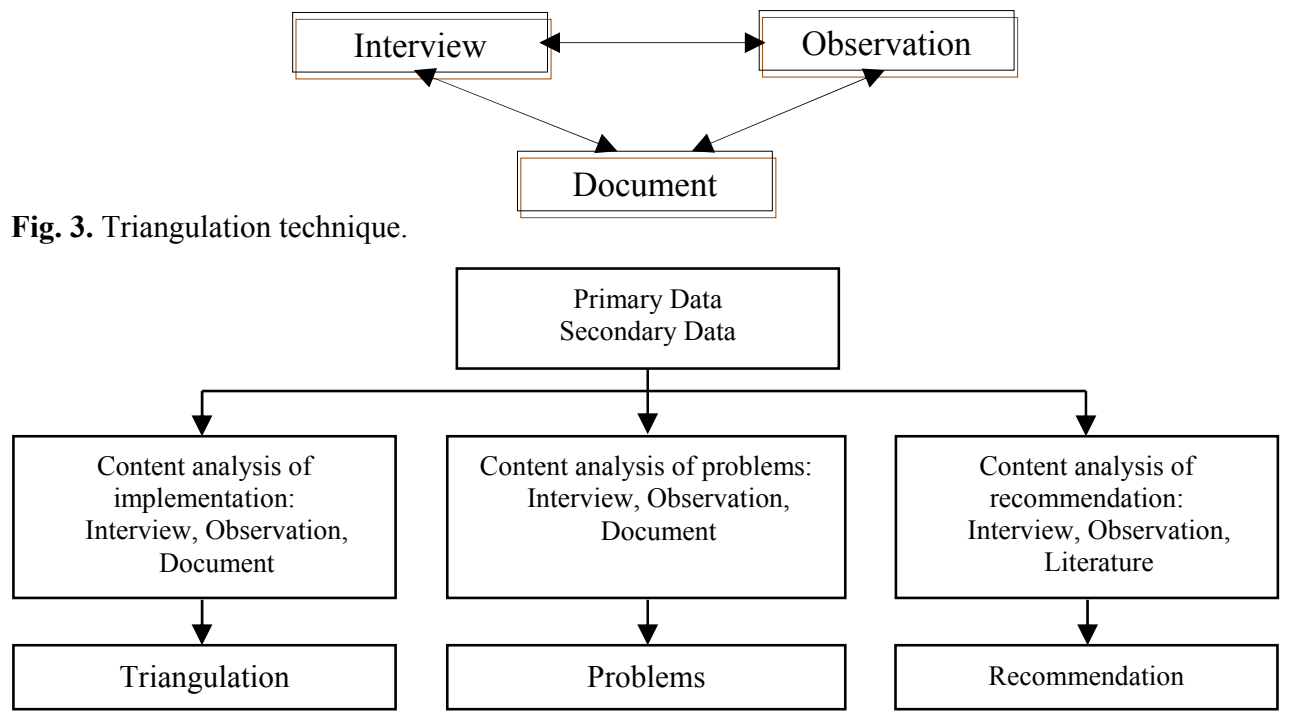

Fig. 4. Flow chart data analysis and discussion.

\section{Results and discussion}

A number of indicators were taken from the technical guidelines to look into the process of implementing the technical guidelines of DAK. The indicators can be found in Table 1.

Table 1. DAK implementation parameters - 2017 road project.

\begin{tabular}{|c|c|c|}
\hline No. & Component & Indicator \\
\hline \multirow{6}{*}{1} & \multirow{6}{*}{$\begin{array}{l}\text { Planning and } \\
\text { programming }\end{array}$} & 1. URK verification by the authorities \\
\hline & & 2. Planning URK and the proposal for changes \\
\hline & & $\begin{array}{l}\text { a. Listing the roads and bridges to be built } \\
\text { - In accordance with the Road Status Decree }\end{array}$ \\
\hline & & $\begin{array}{l}\text { b. Listing the road link priorities that are to be built } \\
\text { - In accordance with national priorities }\end{array}$ \\
\hline & & $\begin{array}{l}\text { c. Planning the construction stages of the roads and bridges } \\
\text { - Procedural surveying of the road conditions } \\
\text { - Standard procedure of building roads and bridges }\end{array}$ \\
\hline & & $\begin{array}{l}\text { d. Planning activity platform } \\
\text { - According to a strategic plan (RPJMN) }\end{array}$ \\
\hline
\end{tabular}




\begin{tabular}{|c|c|c|}
\hline No. & Component & Indicator \\
\hline & & $\begin{array}{l}\text { - Format plan on the activity platform in accordance with } \\
\text { DAK } 2017\end{array}$ \\
\hline 2 & Technical planning & Application of standards and guidelines from MPWH \\
\hline \multirow[t]{3}{*}{3} & \multirow[t]{3}{*}{ Construction activity } & 1. Contract document using the specifications of MPWH \\
\hline & & $\begin{array}{l}\text { 2. Contract documents in accordance with the current } \\
\text { regulations (Perpres and Permen PU latest) }\end{array}$ \\
\hline & & 3. The work is completed and accepted by the service user \\
\hline 4 & Reports & $\begin{array}{l}\text { Activity implementation report DAK } \\
\text { - Material report } \\
\text { - Preparation and submission of quarterly reports } \\
\text { - Online DAK reporting and updates }\end{array}$ \\
\hline
\end{tabular}

\subsection{DAK Implementation}

The process of analyzing the content of the DAK implementation in the study sites was conducted by analyzing the interview results from the DAK recipients and the DAK inspectors, and by examining the documents as shown in Table 2 and Fig. 5 below.

Table 2. Example coding process.

\begin{tabular}{|c|c|c|c|c|c|}
\hline \multirow{3}{*}{ No } & \multirow{3}{*}{ Component } & Inspector & \multicolumn{3}{|c|}{ Recipient } \\
\hline & & All city & Payakumbuh & Bukittinggi & Solok \\
\hline & & \multicolumn{4}{|c|}{ Text code } \\
\hline 1 & $\begin{array}{l}\text { Planning and } \\
\text { Programming }\end{array}$ & $\begin{array}{l}\text { M2.1; M2.2; } \\
\text { M3.1; M1.1; } \\
\quad \text { M1.6 }\end{array}$ & & & \\
\hline 2 & $\begin{array}{l}\text { URK verification by } \\
\text { authorised officials }\end{array}$ & & $\begin{array}{l}\text { P1.6; P2.2; } \\
\text { P3.8 }\end{array}$ & $\begin{array}{l}\mathrm{B} 1.2 ; \mathrm{B} 1.3 \\
\mathrm{~B} 2.5 ; \mathrm{B} 3.4\end{array}$ & S3.2 \\
\hline 3 & $\begin{array}{l}\text { Listing the roads } \\
\text { and bridges to be } \\
\text { built }\end{array}$ & & $\begin{array}{l}\text { P1.1; P2.1; } \\
\text { P3.1 }\end{array}$ & $\begin{array}{l}\text { B1.1; B2.1; } \\
\quad \text { B3.1 }\end{array}$ & $\begin{array}{l}\text { S1.1; S2.1; } \\
\quad \text { S3.1 }\end{array}$ \\
\hline 4 & $\begin{array}{l}\text { Listing the road link } \\
\text { priorities to be built }\end{array}$ & & $\begin{array}{l}\text { P1.2; P2.3; } \\
\text { P2.6; P3.3 }\end{array}$ & $\begin{array}{l}\mathrm{B} 1.2 ; \mathrm{B} 1.3 ; \\
\mathrm{B} 1.5 ; \mathrm{B} 2.2 ;\end{array}$ & $\begin{array}{l}\mathrm{S} 2.2 ; \mathrm{S} 2.3 ; \\
\mathrm{S} 1.2 ; \mathrm{S} 3.2\end{array}$ \\
\hline
\end{tabular}

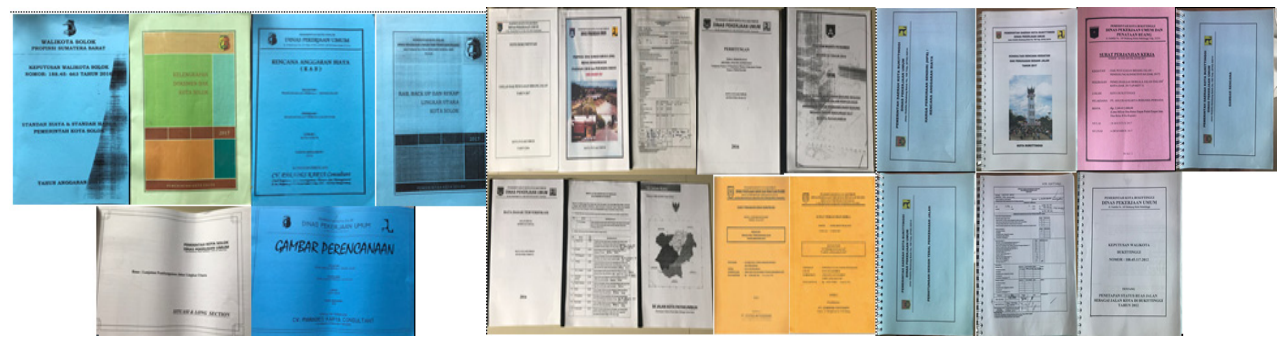

Fig. 5. Implementation document. 
Table 3. Example of DAK implementation cheklist.

\begin{tabular}{|l|l|c|c|c|c|c|c|c|c|}
\hline \multirow{2}{*}{ No } & \multicolumn{7}{|c|}{ Component } & \multicolumn{7}{c|}{ Payakumbuh DAK Implementation } \\
\hline & & Interview & Observation & \multicolumn{2}{c|}{ Document } & \multicolumn{2}{c|}{ Conclusion } \\
\hline & & Y & N & Y & N & Y & N & Y & N \\
\hline 1 & Planning and Programming & & & & & & & & \\
\hline & $\begin{array}{l}\text { Verifying URK by authorised } \\
\text { officials }\end{array}$ & $\sqrt{ }$ & & $\sqrt{ }$ & & $\sqrt{ }$ & & $\sqrt{ }$ & \\
\hline & $\begin{array}{l}\text { Planning URK and proposal for } \\
\text { changes }\end{array}$ & & & & & & & & \\
\hline & $\begin{array}{l}\text { Listing the roads and bridges to } \\
\text { be built }\end{array}$ & $\sqrt{ }$ & & $\sqrt{ }$ & & $\sqrt{ }$ & & $\sqrt{ }$ & \\
\hline & $\begin{array}{l}\text { Listing the road link priorities } \\
\text { to be built }\end{array}$ & $\sqrt{ }$ & & $\sqrt{ }$ & & $\sqrt{ }$ & & $\sqrt{ }$ & \\
\hline & $\begin{array}{l}\text { Planning the construction stages } \\
\text { of the roads and bridges }\end{array}$ & $\sqrt{ }$ & & $\sqrt{ }$ & & & $\sqrt{ }$ & & $\sqrt{ }$ \\
\hline & Planning the activity platform & $\sqrt{ }$ & & $\sqrt{ }$ & & $\sqrt{ }$ & & $\sqrt{ }$ & \\
\hline etc.... & & & & & & & \\
\hline
\end{tabular}

After the checklist was ticked, it was compared using the triangulation technique. Therefore, the implementation of DAK on the roads in 2017 is summarised in Fig. 6.

Determination of plannning program for roads and bridges A report every three months Content report Hand over

Legal contract

Legal contract added with some requirements

Employing the standards and guideline of Kemen. PUPR

Planning the activity platform

Listing the road link priorities

Listing the roads and bridges

Verifying URK by authorised officials

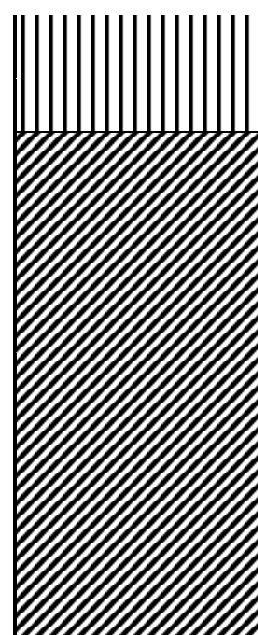

PAYAKUMBUH

Note :

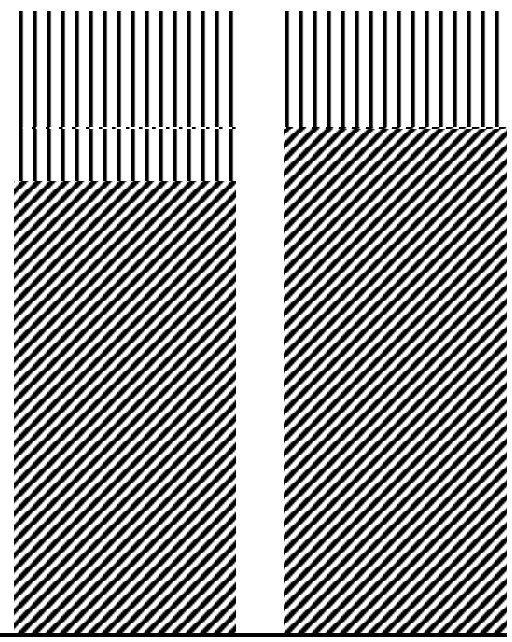

BUKITTINGGI SOLOK
: The activities are executed in accordance with the technical guidelines : The activities are not executed in accordance with the technical guidelines

Fig. 6. Implementation summary. 


\subsection{Problems and recommendations}

The results of the content analysis of the interviews with the recipients and inspectors, and the results from the documents from each city, have been summarised comprehensively as shown in Fig. 7.

Payakumbuh

Bukittinggi

Solok

\begin{tabular}{|c|c|c|}
\hline No. & Problems & Recommendations \\
\hline 1. & $\begin{array}{l}\text { - Difficulties in implementing the } \\
\text { road condition surveys } \\
\text { - The absence of road condition } \\
\text { survey results } \\
\text { - Difficulties in operational / } \\
\text { offline } \\
\text { - Lack of technical staff }\end{array}$ & $\begin{array}{l}\text { To improve the capability of personnel in DAK } \\
\text { management, as it is essential to conduct: } \\
\text { - Socialisation of the DAK Technical Guidelines } \\
\text { outside of the Regional Consultation. } \\
\text { - Implementation of training / technical guidance } \\
\text { in the Public Works Office and service } \\
\text { providers, especially in relation to the technical } \\
\text { planning and construction trainings at the }\end{array}$ \\
\hline
\end{tabular}




\begin{tabular}{|c|c|c|}
\hline No. & Problems & Recommendations \\
\hline & $\begin{array}{l}\text { - Lack of knowledge in planning } \\
\text { - Low capacity of the planning } \\
\text { consultants } \\
\text { - Low standard of building } \\
\text { drawings } \\
\text { - The conventional methods of } \\
\text { planning pavement thickness } \\
\text { - Obstacles to the provision of } \\
\text { resources in the implementation } \\
\text { of construction }\end{array}$ & $\begin{array}{l}\text { beginning of the fiscal year. } \\
\text { - Preparation of training activities by the } \\
\text { Ministry of Public Work and People's Housing } \\
\text { in coordination with the Public Work Office. } \\
\text { - Employment of personnel/DAK staff (more } \\
\text { than one person) in order to anticipate the } \\
\text { absence of DAK personnel at short notice. } \\
\text { - Integration of DAK-related programs/software } \\
\text { to facilitate the operations. }\end{array}$ \\
\hline 2. & $\begin{array}{l}\text { - Delay of the DPA's demise } \\
\text { process } \\
\text { - Delay of the completion of } \\
\text { construction work - lateness } \\
\text { - Fund disbursement constraints }\end{array}$ & $\begin{array}{l}\text { - The process of an early auction in the first } \\
\text { quarter of each fiscal year. } \\
\text { - Implementation of a Regional Consultation and } \\
\text { DAK verification by MPWH at the beginning } \\
\text { of the activity planning stage. } \\
\text { - Publishing technical guidelines for DAK } \\
\text { implementation at the beginning of the process } \\
\text { planning. }\end{array}$ \\
\hline 3. & $\begin{array}{l}\text { - Delay of the E-monitoring } \\
\text { report } \\
\text { - Neglect of the quarterly report }\end{array}$ & $\begin{array}{l}\text { - Periodic monitoring in the field. } \\
\text { - Systematic supervision by involving inspectors } \\
\text { in their respective areas }\end{array}$ \\
\hline
\end{tabular}

\section{Conclusions}

Based on the findings from this study, some points can be concluded as follows. The ten indicators of DAK were performed by Payakumbuh and Solok city along with the production of a comprehensive and standardized report. On the other hand, Bukittinggi city only performed nine of the indicators and failed to provide a standardized report. The submission of a quarterly report to the inspectors failed to be done by the three cities, but the researchers received the report. Also, the three cities did not survey to check the road conditions following what it is instructed in the technical guidelines.

The results of the DAK implementation assessment from the activity monitors that had no impact on the acquisition of the DAK amount in the following year open up opportunities for the technical guidance to not be implemented thoroughly.

DAK Technical Guidance No. 33 of 2016 is sufficiently comprehensive to explain the implementation of DAK activities in relation to the components of planning and programming, construction, implementation, and reporting. However, the explanations referring to the technical planning components in the technical guidelines are very limited and vague.

\section{References}

1. Directorate General of Highways. The strategic plan of the directorate general of highways 2015-2019 (2015) 
2. Pemerintah Republik Indonesia. Peraturan Pemerintah Republik Indonesia no 55 tahun 2005 tentang Dana Perimbangan (Presiden Republik Indonesia, Jakarta, 2005)

3. F.N. Widiarni. Intention in involving the activities of social organizations during retirement (Thesis, Jakarta, 2013)

4. Sugiyono. Quantitative, qualitative and $R \& D$ research methods (Alfabeta, Bandung, 2017)

5. H.H. Sahid, Analysis of qualitative content, customs and excise, organizational image, customs protection, directorate general of customs and excise, public relations, public relations media NET TV (Thesis, Universitas Gadjah Mada, Yogyakarta, 2017)

6. Menteri Pekerjaan Umum dan Perumahan Rakyat Republik Indonesia. Peraturan Menteri Pekerjaan Umum dan Perumahan Rakyat Republik Indonesia No 33/PRT/M/2016 tentang Petunjuk Teknik Penyelenggaraan Dana Alokasi Khusus Bidang Infrastruktur (Kementerian PUPR, Jakarta, 2016)

7. H. Martadwiprani, D. Rahmawati, J. Teknik Pomits 2, 2 (2013) 